\title{
A myeloma multiplex megközelítése Magyarországon 2016-ban
}

\author{
Varga Gergely dr. ${ }^{1}$ - Mikala Gábor dr. ${ }^{2}$ \\ Váróczy László dr. ${ }^{3}$ - Illés Árpád $\mathrm{dr}^{3}{ }^{3}$ \\ ${ }^{1}$ Semmelweis Egyetem, Általános Orvostudományi Kar, \\ III. Belgyógyászati Klinika, Haematológiai részleg, Budapest \\ ${ }^{2}$ Egyesített Szent István és Szent László Kórház-Rendelőintézet, \\ Hematológiai és Őssejt-transzplantációs Osztály, Budapest \\ ${ }^{3}$ Debreceni Egyetem, Általános Orvostudományi Kar, Belgyógyászati Intézet, \\ Hematológiai Tanszék, Debrecen
}

\begin{abstract}
A myeloma multiplex kezelése az elmúlt évtizedben óriásit változott. Mind a kemoterápiás protokollok, mind a szupportív kezelés nagy fejlődésen ment át, amióta a legutóbbi magyar ajánlás megjelent. A betegek egyre nagyobb része ér el tartós választ, és mind többük számára van talán esély a gyógyulásra is. Az összefoglaló célja, hogy az utóbbi évek eredményeit is beépítve, az érvényes nemzetközi ajánlásokat a magyar viszonyok sajátosságaihoz adaptálva segítse a betegek leghatékonyabb kezelését. Orv. Hetil., 2016, 157(4), 123-137.
\end{abstract}

Kulcsszavak: myeloma multiplex, autológ őssejt-transzplantáció, bortezomib, lenalidomid, irányelv

\section{Management of multiple myeloma in Hungary in 2016}

The last decade has witnessed a dramatic progress in the treatment of multiple myeloma. Both the chemotherapy protocols and the supportive therapy options have improved significantly since the publication of the previous Hungarian national guideline. An increasing proportion of patients now reach a durable response and cure became a potential option for some. The aim of the authors was to adapt the international guidelines to the specific circumstances of the Hungarian healthcare system in the light of the most recent developments.

Keywords: multiple myeloma, autologous stem cell transplantation, bortezomib, lenalidomide, guideline

Varga, M., Mikala, G., Váróczy, L., Illés, Á. [Management of multiple myeloma in Hungary in 2016]. Orv. Hetil., 2016, 157(4), 123-137.

(Beérkezett: 2015. október 25.; elfogadva: 2015. november 26.)

\section{Rövidítések}

ASCT = autológ őssejt-transzplantáció; $\mathrm{CRAB}=$ hypercalcaemia, veseelégtelenség, anaemia, csontlaesiók; FISH = fluoreszcens in situ hibridizáció; FLC = szérum-könnyúlánc; GEP = génexpressziós profil; $\operatorname{IgH}=$ immunglobulin-nehézlánc; IMWG = International Myeloma Working Group; ISS = International Staging System; MAPK = mitogénaktivált proteinkináz; MGUS = monoclonal gammopathy of undetermined significance; $\mathrm{MM}=$ myeloma multiplex; NGS $=($ next generation sequencing) új generációs szekvenálás; R-ISS = Revised International Staging System; SBP = (single nucleotide polymorphism) egy nukleotidot érintő polimorfizmus; VAD = vincristin, doxorubicin, dexamethason; $\mathrm{WHO}=$ Egészségügyi Világszervezet
A myeloma multiplex (MM) rosszindulatú hematológiai megbetegedés, amelyet malignusan átalakult, klonális plazmasejtek csontvelői burjánzása jellemez. Az Egészségügyi Világszervezet (WHO) osztályozása szerint érett (perifériás) B-sejtes neoplazma. A várható túlélés az utóbbi évtizedekben megjelent számos új, potens kezelési lehetőség eredményeképpen sokat javult, a jó prognosztikai csoportban csontvelő-átültetéssel a túlélés elérheti a 10 évet [1]. A legutóbbi általános igényú magyar myeloma-összefoglaló [2] megjelenése óta a nemzetközi ajánlásokat többször frissítették, a diagnózissal kapcsolatos legutóbbi International Myeloma Working Group 
(IMWG) ajánlás 2014-ben jelent meg néhány fundamentális változással [3].

Magyarországon évente mintegy 350-400 új MM-beteg jelentkezésével lehet számolni. Ha feltételezzük, hogy ma átlagosan körülbelül 5 évig él egy myelomás beteg, akkor ez mintegy 1500 gondozott beteget jelenthet. Évente 120-150 autológ transzplantáció (ASCT) történik myelomában Magyarországon, jellemzően első vonalban.

Előfordulása a férfiak között valamivel gyakoribb; 40 éves kor alatt csak ritkán fordul elő, ezután a korral párhuzamosan nő a gyakorisága, az átlagéletkor a diagnóziskor 65 év. Az irodalom szerint a betegek 55-60\%-a csontfájdalmakkal, leggyakrabban derék- vagy hátfájással fordul orvoshoz. Nemritkán patológiás fractura az első tünet, és a stabilizációs mütét során vett szövettani minta adja a diagnózist. Más esetben a csontvelő-elégtelenség (anaemia, thrombocytopenia) vagy az immunszuppreszszió okozta infekciók a vezető tünetek, és a csontrendszeri eltérések hiányoznak [4]. Az esetek 10\%-ában veseelégtelenség az első tünet, amiben a könnyü láncok kicsapódása miatti cylindernephropathia mellett a fokozott osteoclast-tevékenység okozta hypercalcaemiának is szerepe lehet.

A myeloma a betegek egy kisebb részénél tünetmentesen („smouldering” forma) jelentkezik, őket sokszor elégséges megfigyelni hosszú éveken át, nem szükséges kezelés, míg a betegek nagyobb részének általában 2-3 évente ismételten kezelésekre kell számítania.

A következőkben áttekintjük a myeloma biológiájával kapcsolatos újabb információkat, a betegség diagnózisához és stádiummegállapításához szükséges vizsgálatokat, illetve a kezelési lehetőségeket. Ahol ismertek, ott alkalmazzuk az evidenciaszintek megszokott jelöléseit.

\section{A myeloma multiplex biológiája}

Az MM kialakulásáról rengeteg új információt kaptunk az utóbbi években, de még messze vagyunk attól, hogy ez egy egységes képbe állna össze, és szemben például az akut leukaemiákkal, a genetikai információknak egyelöre csak limitált kihatásuk van az egyes betegek kezelésére.

Az MM klinikailag rendkívül sokszínű betegség, ami nagymértékben az alapjául szolgáló genetikai eltérések heterogenitásából következik. Az utóbbi években számos újabb technikával (SNP array, génexpresszós profil [GEP], új generációs szekvenálás [next generation sequencing - NGS]) gazdagodott eszköztárunk, amelyek alapján legalább nyolcféle alapvető biológiai szubtípust mutató és eltérő klinikai viselkedésü betegségformát különíthetünk el. Ezt szokás TC-klasszifikációnak nevezni (1. táblázat) [5], ahol a T a betegséget „alapító” genetikai eltérésre, transzlokációra utal, míg a C a szubtípusra jellemző cyclinfehérje kifejeződésére [6].

A myeloma patogenezisében kétféle alapító eltérést szokás megkülönböztetni: a hiperdiploiditást és az immunglobulin-nehézlánc (IgH) locust érintő transzloká- ciókat; ez a két eltérés két megközelítően egyforma elemszámú csoportra osztja a myelomás betegeket. Hiperdiploiditás alatt a páratlan kromoszómák számbeli felszaporodását értjük, ez leggyakrabban a 3-as, 5-ös, 7-es, 9-es, 11-es, 15-ös, 19-es és 21-es kromoszómák valamelyikének vagy többjének sejtenkénti három kópiáját jelenti. Az Ig-nehézlánc-régió transzlokációi leggyakrabban a cyclin D, MMSET és MAF gének kifejeződését érintik. Eltérő mechanizmussal, de mindkét csoportra jellemző a cyclin D1 vagy D2 fokozott expressziója [6, $7]$.

A hiperdiploid myeloma az átlagosnál valamivel gyakoribb idősebb korban, és jellemzője a viszonylag sok csontlaesio, a terápiákra adott relatíve jó válasz, és ritka a primer terápiarezisztencia.

Az IgH gént érintő transzlokációk közül öt fordul elő nagyobb gyakorisággal, és mindegyik klasszikus tumorbiológiai és klinikai következménnyel jár. A leggyakoribb a $\mathrm{t}(1 \mathrm{l} ; 14)(\mathrm{IgH} / \mathrm{cyclin} \mathrm{Dl})$, következményes igen magas cyclin Dl-expresszióval. A prognózis általában jó, egyes vizsgálatok szerint kiemelkedően jó az ASCT-re adott válasz. Ezt követi a t(4;14)-transzlokáció (IgH/ MMSET), következményes magas szintű MMSET és FGFR3 fehérjetermeléssel, klinikailag akcelerált betegségviselkedéssel, de nagy érzékenységgel proteoszómagátló terápiákkal szemben. Körülbelül 2-2\% gyakoriságú a t $(6 ; 14)(\mathrm{IgH} /$ cyclin D3), a t $(14 ; 16)(\mathrm{IgH} / \mathrm{MAF})$ és a $\mathrm{t}(14 ; 20)(\mathrm{IgH} / \mathrm{MAFB})$. E transzlokációk magas cyclin D3-kifejeződéssel, illetve a MAF fehérjék fokozott termelődésével járnak (ez pedig fokozza a cyclin D2 termelődését). A MAF-csoportban a klasszikus csontlaesiók viszonylag ritkák, ennek oka a Dickopf-fehérje alacsony kifejeződése. A prognózis általában kedvezőtlen. 2\% alatti gyakorisággal több mint 30-féle egyéb transzlokációt írtak le, de ezek klinikai jelentőségét ritkaságuk miatt nem ismerjük. A betegek mintegy $2 \%$-ában nem fokozott egyetlen cyclin D fehérje kifejeződése sem, itt gyakori közös esemény a retinoblastoma tumorszuppresszorgén-hiányos kifejeződése $[6,7]$.

A fenti elsődleges, „alapító” genetikai eltérések mellett számos egyéb gyakori genetikai eltérést ismerünk myelomában. Három visszatérő eltérésról van viszonylag sok adatunk, ezek a 13ql4-régiót érintő deléciók, a 17p13-régiót érintő deléciók és az lq21-amplifikáció. Mindhárom eltérés azonosítása valamilyen mértékben kedvezőtlen kórjóslatot jelez, de a 17p-deléció kivételével a pontos kóroki tényező, a kritikus gén vagy génszakasz mibenléte még vitatott. Az értelmezést nehezíti, hogy ezek a másodlagosnak tekinthető eltérések gyakran kapcsoltan és további citogenetikai eltérések mellett vannak jelen, így egy-egy kromoszómaszakasz vesztésének vagy nyerésének direkt következménye nehezen meghatározható. Az lq21-amplifikáció a monoterápiákkal szemben általában rezisztenciát okoz, de a hármas kombinációk jellemzően hatékonyak. A 17p-deléció a TP53 tumorszuppresszor gén egyik kópiájának elvesztését jelzi, ami haploinsufficientiát okoz. Mi több, gyakori a 
1. táblázat |A myeloma TC-klasszifikációja Fonseca és mtsai alapján [5]

\begin{tabular}{|c|c|c|c|}
\hline Alcsoport & Genetikai esemény & Előfordulás & Klinikai és laboratóriumi jelek \\
\hline Hiperdiploid & $\begin{array}{l}\text { Páratlan kromoszómák } \\
\text { triszómiája }\end{array}$ & $45-50 \%$ & $\begin{array}{l}\text { Kedvező prognózis, gyakran idősebb betegek, } \\
\text { gyakrabban IgG-kappa, általában jól reagál a kezelésekre }\end{array}$ \\
\hline \multirow[t]{3}{*}{ Cyclin D-transzlokáció } & $\mathrm{t}(11 ; 14)(\mathrm{q} 13 ; \mathrm{q} 32)$ & $15-20 \%$ & $\begin{array}{l}\text { CCNDl upreguláció, kedvező prognózis, csontlaesiók, } \\
\text { GEP alapján két további alcsoport }\end{array}$ \\
\hline & $\mathrm{t}(6 ; 14 \mathrm{q})(\mathrm{p} 21 ; 32)$ & $2 \%$ & Hasonló az előzőhöz \\
\hline & $\mathrm{t}(12 ; 14)(\mathrm{p} 13 ; \mathrm{q} 32)$ & $<1 \%$ & Ritka \\
\hline \multirow[t]{3}{*}{ MAF-transzlokáció } & $\mathrm{t}(14 ; 16)(\mathrm{q} 32 ; \mathrm{q} 23)$ & $2 \%$ & Agresszív \\
\hline & $\mathrm{t}(14 ; 20)(\mathrm{q} 32 ; \mathrm{q} 11)$ & $2 \%$ & Agresszív \\
\hline & $\mathrm{t}(8 ; 14)(\mathrm{q} 24 ; \mathrm{q} 32)$ & $1 \%$ & Valószínúleg agresszív \\
\hline MMSET/FGFR3 transzlokáció & $\mathrm{t}(4 ; 14)(\mathrm{pl} 6 ; \mathrm{q} 32)$ & $15 \%$ & $\begin{array}{l}\text { MMSET- és FGFR3-upreguláció, konvencionális } \\
\text { kezeléssel kedvezőtlen prognózis, csontlaesiók nem } \\
\text { jellemzők }\end{array}$ \\
\hline Cyclin D-expresszió nem fokozott & Hiányzó RB-expresszió & $2 \%$ & \\
\hline Nem klasszifikált & & $10-15 \%$ & Sok, nem jól elkülönülő alcsoport \\
\hline
\end{tabular}

GEP = génexpressziós profil.

megmaradt egyetlen p53 gén inaktiváló pontmutációja, amelynek következménye a TP53-függó apoptózisfolyamatok elvesztése. Ez a legtöbb citosztatikummal és sugárterápiával szemben nagyfokú rezisztenciát eredményez, de a szteroid hatására bekövetkező apoptózist nem befolyásolja.

A genomszekvenálási vizsgálatok myeloma esetében nem azonosítottak a betegségre jellemző egyetlen karakterisztikus eltérést, a betegség hosszú evolúciója azonban eredményezheti a szolid tumorokéhoz hasonló nagyságrendû pontmutáció akkumulációját [8]. Újonnan diagnosztizált myeloma esetén karakterisztikusnak, de nem specifikusnak mondható a MAPK (mitogénaktivált proteinkináz) szignálutat aktiváló mutációk jelenléte (az esetek 60\%-ában kimutatható, míg primer plazmasejtes leukaemiában ritkának mondható) [9-11]. A RASmutációk gyakorisága/kimutathatósága az MM előrehaladása kapcsán nő: NRAS 23-24\%, KRAS 26-33\%. A szignálutakat érintő eltérések között gyakoriak még az aktiváló BRAF-mutációk, akár 12\%-os előfordulással $[12,13]$. Leggyakoribbak a klasszikusnak mondható V600 tripletet érintő mutációk, de legalább tízféle egyéb BRAF missense mutáció is előfordul MM-ben [13]. A MAPK útvonaltól eltérő szignálutakból kiemelhető még az NFkB útvonal tagjait érintő mutációk (kumulatív 17\% gyakorisággal), a mind ez ideig ismeretlen funkciójú FAM46C gént érintő mutációk 13\%-os és a TP53 inaktiváló eltérések 8\%-os gyakorisága. Többszörösen előkezelt myeloma esetén a fenti mutációk gyakrabban és komplexebben fordulnak elö, plazmasejtes leukaemiában a TP53-mutáció gyakorisága akár 83\% lehet.

A genomikai munkák előretörése mellett említésre méltó és klinikai jelentőségű a génkifejeződés vizsgálata is, amely myeloma esetében elsősorban RNS-szintű génexpressziós profilírozást jelent. Génexpressziós vizsgálatok vezettek két olyan klasszikus klinikai képpel jellemez- hető myeloma-szubtípus felismeréséhez, ahol az expressziós profil és nem az alapító genetikai eltérés határozta meg a viselkedést. E két csoport a proliferatív és a „low bone" csoport. A proliferatív-csoport közös jellemzője a sejtproliferációval kapcsolatos gének myelomában szokatlanul magas kifejeződése (az R-ISS besorolásba ezt a tényezôt a magas LDH-érték viszi be), míg a low bone alcsoport klinikailag a típusos csontlaesiók hiányával és megtartott csontszerkezettel jellemezhetó [14]. Ennek oka valószínúleg az endothelin-1 magas és a Dickopf/frizzledB fehérjék alacsony kifejeződése.

A közelmúlt tumorbiológiájának - a terjedő új generációs szekvenálási technikáknak köszönhető - fontos felismerése az egyetlen betegen belül is észlelhető tumorheterogenitás. MM esetében - akár egyetlen betegben mind térbeli, mind pedig időbeli heterogenitás bizonyított $[9,14,15]$. Ez azt jelenti, hogy már az első vizsgálat idején jellemzően több tumorklón van párhuzamosan jelen: közös alapító citogenetikai profil mellett eltérő másodlagos eltérések (például 13q-, 17p-, +1q21) mutathatók ki. Eltérő aspirációs helyekről vett mintákban a kimutatott genetikai eltérések aránya különbözhet. Konvenció szerint, ha egy genetikai eltérés a plazmasejtek kevesebb mint 60\%-ában mutatható ki, szubklonális eltérésről beszélünk. Az eltérő szubklónok eltérő farmakológiai érzékenységet mutathatnak, következésképp eltérően reagálhatnak az alkalmazott terápiára, ami klonális „ár-apály” jelenséget eredményez: a terápia szelekciós nyomást gyakorol a daganatra és az adott terápiára ellenálló sejtek szaporodásának relatíve kedvez [12, 16-18].

A klonális ár-apály mellett egyértelmú a longitudinális evolúció bizonyítottsága is. Ez azt jelenti, hogy terápia hatására nemcsak a már meglévő klónok szervezeten belüli aránya változik meg, hanem a klónokon belül új genetikai eltérések is megjelennek, amelyek korábbi mintákban nem voltak kimutathatók [19]. Ennek esélye 
azonban betegségfüggő: elsősorban a hiperdiploid-alcsoportban jellemző a nagyfokú genetikai stabilitás, amelyeknél az új eltérések megjelenésének az esélye kicsi ( „non-evolving”, 37\%). Ugyanakkor nagy rizikójú MM esetén $[\mathrm{t}(4 ; 14), \mathrm{t}(14 ; 16), \mathrm{t}(14 ; 20), 17 \mathrm{p}$ - $]$ sokkal nagyobb az új eltérések megjelenésének valószínúsége [14, 16]. 17p- eltérés esetén például, ahol akadályozott a DNS-károsodás kiváltotta apoptózis, jellemzően nagyszámú egyéb genetikai eltérés is kimutatható.

A legújabb tumorbiológiai eredmények a mindennapi MM-kezelési gyakorlatot egy ponton kell, hogy érintsék: tekintettel több myelomaklón egy betegen belüli egyidejü jelenlétének széles körü bizonyítottságára, mivel az alapító eltérésre célzott terápiával jelenleg nem rendelkezünk, olyan kezelési módot kell választanunk, amely minél több szubklónt képes eredményesen gátolni: a monoterápiák ideje lejárt [19].

\section{A myeloma multiplex diagnosztikája}

A 2014. évi IMWG guideline alapvetően megváltoztatta a korábbi diagnosztikus kritériumrendszert. Egyrészt a kritériumok közül kikerült az M-protein, ami logikus, hiszen van könnyúlánc- és nonszekretoros myeloma is. Ugyanakkor egy korábban ultramagas rizikójú smouldering myelomaként aposztrofált csoport most korai myelomaként kerül definiálásra, ami egyben azt is jelenti, hogy ez az (egyébként nem túl nagy) csoport is kezelést igényel. Erre az utóbbi változtatásra azért került sor, mert ezek a betegek $80 \%$ eséllyel progrediáltak 2 éven belül (2. táblázat) [3].

Az MM kritériumai tehát: I. klonális plazmasejt-szaporulat a csontvelőben (arányuk eléri vagy meghaladja a 10\%-ot) vagy szoliter plasmocytoma formában, és vagy II. szervi károsodások (amelyeket az angol CRAB mozaikszó foglal össze: hypercalcaemia [C], veseelégtelenség [R], anaemia [A], csontlaesiók [B]), vagy III. a legutóbbi IMWG-ajánlásban megjelent három új biológiai tényező valamelyike: a $60 \%$ feletti csontvelői plazmasejtarány, a 100 feletti szérumszabadkönnyưlánc-arány és az egynél több fokális myelomás laesio MRI-vel vizsgálva [3].

\section{Csontvelövizsgálat és szövettani mintavétel}

A betegség gyanúja esetén csontvelői mintavétel szükséges, amely lehet aspiráció vagy biopszia. A legegyszerúbb és - gyakorlott diagnoszta esetén - még ma is pontosnak mondható módszer a May-Grünwald-Giemsa szerint megfestett kenet vizsgálata. Hagyományosan a 10\% feletti plazmasejt-szaporulatot tekintjük kórosnak, bár ma már egyre inkább törekedni kell arra, hogy a plazmasejtek klonalitását bizonyítsuk. Ennek egyik eszköze a citoplazmában elhelyezkedő monoklonális immunglobulin kimutatása immunperoxidáz festéssel vagy immunfluoreszcenciával [20].

A kóros és normális plazmasejtek elkülönítésének legkorszerúbb módszere ma az áramlási citometria. A plazmasejtek unikális sejtfelszíni markere a CD138 molekula, a szindekán, emellett változó intenzitású CD38-expreszszió is megfigyelhető. A malignus plazmasejtek CD19negatívak és CD56-pozitívak, míg a normális változatuk CD19-pozitív, CD56-negatív fenotípusú, így elsősorban ezek a markerek alkalmasak a kétféle sejttípus differenciálására. A myelomasejtek érettségének, proliferációs aktivitásának megállapítására használható a CD27 és CD117

2. táblázat |A monoklonális paraproteinaemiák elkülönítése az International Myeloma Working Group legújabb ajánlása szerint (Rajkumar és mtsai alapján, módosítva [3])

\begin{tabular}{|c|c|c|c|}
\hline & MGUS & Smouldering myeloma & Myeloma multiplex \\
\hline Az M-protein típusa & $\operatorname{IgG}, \operatorname{Ig} A, \operatorname{Ig} M$ & $\operatorname{IgG}, \operatorname{Ig} A^{*}$ & $\operatorname{IgG}, \operatorname{Ig} A^{*}$ \\
\hline Az M-protein mennyisége & $\leq 30 \mathrm{~g} / 1$ & $>30 \mathrm{~g} / 1$ & \\
\hline Klonális csontvelői plazmasejtek & $\leq 10 \%$ & $10-60 \%$ & $>10 \%$ \\
\hline (C) Hypercalcaemia & Nincs & Nincs & Lehet** \\
\hline (R) Veseelégtelenség*** & Nincs & Nincs & Lehet** \\
\hline (A)naemia & $\mathrm{Hb}>100 \mathrm{~g} / 1$ & $\mathrm{Hb}>100 \mathrm{~g} / 1$ & Lehet, általában van** \\
\hline (B) Lyticus csontlaesiók**** & Nincsenek & Nincsenek & Lehetnek, általában vannak** \\
\hline \multirow[t]{3}{*}{ Ha nincs CRAB } & & & Csontvelői plazmasejt $>60 \%$ ** \\
\hline & & & FLC-arány $>100 * *$ \\
\hline & & & MRI-laesiók száma >1 * * \\
\hline
\end{tabular}

* Ritkán $\operatorname{IgD}, \operatorname{IgM}, \operatorname{IgE}$.

**Valamelyik fennáll

$* * * \mathrm{GFR}<40 \mathrm{ml} /$ perc

****Csontröntgennel vagy CT-vel vizsgálva, ha a csontvelői plazmasejtek aránya nem éri el a 10\%-ot, akkor több laesio szükséges, hogy a plasmocytomától elkülönítsük a myelomát.

FLC = szérum-könnyúlánc; MGUS = monoclonal gammopathy of undetermined significance. 
jelölés. Mivel a plazmasejtek sérülékenyek és a szeparálás során jelentős részük elvész, az aspirátummintából történő áramlási citometria nem alkalmas a csontvelói infiltráció mértékének megállapítására, de kimutatja a plazmasejt-populáción belül a kóros sejtek arányát. A módszer jelenleg a nagyobb egyetemi, megyei centrumokban elérhető, és a diagnózis felállítása mellett lehetőséget ad a minimális residualis betegség (MRD) követésére is [21].

Ha biopsziát végzünk, a minta értékelésekor immunfluoreszcens festési eljárás (CDI38) segítségével viszonylag nagy pontossággal megállapítható a csontvelőn belül a plazmasejtek aránya és lokalizációja.

A betegség biológiájának tárgyalásakor már szó esett a genetikai eltérések fontosságáról a prognózis során. A hagyományos citogenetika - a metafázis-kromoszómák hiánya miatt - nem alkalmas a jelentőséggel bíró változások megállapítására, helyette inkább a fluoreszcens in situ hibridizáció (FISH) módszere használandó. Meg kell említeni, hogy az IMWG-ajánlások szerint FISH-vizsgálatot csak plazmasejt-szelekció után szabadna végezni, de ezt jelenleg Magyarországon egyik centrum sem alkalmazza.

Nehéz meghatározni, mely FISH-eltérések azok, amelyek ismerete feltétlenül szükséges egy myelomás beteg megfelelő kezeléséhez. A kép az egyik oldalon folyamatosan változik: új prognosztikai faktorok jelennek meg, így például a hiperdiploid csoporton belül kitúnt, hogy míg a 3-as és 5-ös kromoszóma megtöbbszöröződése relatíve jó prognosztikai jel, még akkor is, ha más, egyébként negatív abnormalitáshoz [például $\mathrm{t}(4 ; 14)$ vagy del(17p)] kapcsolódik, addig a 2l-es triszómia rossz prognózissal párosul. A másik oldalon minden vizsgálatnak költségvonzata van, és a patológiai vizsgálatok alulfinanszírozottsága arra kényszerít, hogy egyfajta konszenzusajánlással lépjünk fel. Ennek alapján minimálisan szükségesnek tartjuk a t( $4 ; 14), \mathrm{t}(14 ; 16)$ és del $(17 \mathrm{p})$, illetve ideálisan fontosnak az lq- és lp-anomáliák vizsgálatát (2B).

Külön kérdés, hogy mely vizsgálatok indokoltak relapsusban, fóleg ha a beteg már diagnóziskor magas rizikójú volt. Véleményünk szerint a del(17p) és lq21 újbóli vizsgálata mindenképpen indokoltnak tekinthető. A FISH szerepére a terápia megválasztásában még visszatérünk később.

A még fejlettebb technikák - SNP array, GEP, NGS hazánkban rutinszerúen még nem hozzáférhetók, de a világban már sok centrum alkalmazza valamelyiket standardként a FISH helyett vagy azt kiegészítve [22].

A szövettani mintavétel történhet ossealis vagy extraossealis plasmocytomából is, amelynek meglétére például tumorirányú kivizsgálás során derül fény. A fenti vizsgálatok, beleértve a FISH-t, ilyenkor is elvégzendők, az immunhisztokémiai festés során fontos a már említett CD138 marker használata.

\section{Febérjekimutatások}

A plazmasejtek által termelt monoklonális fehérje (M-protein vagy szabad-könnyúlánc) kimutatása történhet szérumból vagy vizeletből. Szưróvizsgálatként agarózgél vagy kapilláris zóna-elektroforézis alkalmazandó, a kvantitatív meghatározás módszerei a nefelometria és a denzitometriás jelölés. Kis mennyiségú M-komponens kimutatására immunfixációt használunk; a komplett válasz megállapítása ezen vizsgálat negativitása esetén lehetséges. MM-ben a szérum-M-protein-koncentráció a legtöbbször $30 \mathrm{~g} / \mathrm{l}$ feletti, leggyakrabban IgG és IgA típusú, az IgD-, IgE- vagy IgM-myeloma ritkaságnak számít. A vizelet-elektroforézist 24 órán keresztül gyújtött mintából végezzük. A hagyományos Bence-Jones-próba valójában a vizeletben megjelenő könnyú láncok indirekt kimutatását jelenti. Az elmúlt évtizedben váltak elérhetővé az automatizált szabad (nehéz lánchoz nem kapcsolódó) könnyúlánc-immunoassay-k. Segítségükkel meghatározható a szérum abszolút szabad kappa- és lambda-könnyúlánc-koncentrációja, valamint a két érték hányadosa. A teszt szinte valamennyi, korábban nonszekretorosnak gondolt beteg esetén alkalmas arra, hogy követhető markerrel szolgáljon. Ezt figyelembe véve, jelenleg 1\%-ra tehető a szabad-könnyúláncot sem kiválasztó, valódi nonszekretoros esetek aránya [23]. A fenti eljárások ma már elérhetőek a hazai hematológiai centrumokkal együttmúködő laboratóriumokban.

\section{ISS és R-ISS}

Minden újonnan diagnosztizált betegnél szükséges az International Staging System (ISS) meghatározása, amely a szérumalbumin- és -béta-2-mikroglobulin-szint alapján kalkulálható, és a betegeket három jól elkülöníthetô csoportba sorolja (1A). Ez a legegyszerúbben alkalmazható és legszélesebb körben elterjedt prognosztikai rendszer (3. táblázat).

Az IMWG nemrégiben publikált egy 4445, imid-, illetve bortezomibbázisú kezelésben részesülő, klinikai vizsgálatban részt vevő beteg analízisén alapuló új prognosztikai pontrendszert, az R-ISS-t (Revised-ISS), amely a jelenleg is végzett ISS-, FISH-, illetve szérum-LDHeredményeket egyesíti (3. táblázat) [24]. A szerzók javasolják ennek alkalmazását, mivel az individuális FISH, ISS és LDH esetlegesen ellentmondó eredményéhez képest egyszerúbben, a beteggel jobban kommunikálható módon fejezi ki a várható prognózist. Ugyanakkor a béta-2-mikroglobulin ismételt meghatározása nem ad pluszinformációt, ezért a betegség követésére nem javasolt.

\section{Kiegészitó laboratóriumi vizsgálatok}

A vörösvérsejt-süllyedés olcsó, nem specifikus eljárás, ám az MM szempontjából mégis figyelemfelhívó jellel bír, különösen, ha extrém magas értéke csontfájdalommal 
társul. Ismételt végzése azonban nem ad pluszinformációt, nem javasolt. A teljes vérkép meghatározásakor az anaemia mellett bármely cytopenia előfordulhat. Fontos a festett vérkenet (kvalitatív vérkép) készítése is, hiszen plazmasejtes leukaemia esetén a malignus sejtek a véráramba is bekerülnek, illetve látványos, bár nem specifikus eltérés lehet a vörösvérsejtek „pénztekercsképződése". A vesekárosodás megítélésére a szérumurea-, -kreatinin-, GFR- és az általános vizeletvizsgálat szolgál. Hypercalcaemia mintegy 10\%-ban fordul elő. Az összkalcium mellett az ionizált kalcium szintjét is meg kell határozni, mivel a kalcium nagyobbrészt fehérjéhez kötött, ezért a magas összfehérjeszint és a hypoalbuminaemia lehetetlenné teszi az összkalcium helyes értelmezését. Az emelkedett LDH-szint magas sejtproliferációs aktivitásra, rossz prognózisra utal.

\section{Képalkotó vizsgálatok}

Ezen eljárásokkal a myelomás csontlaesiókat és plasmocytomákat mutatjuk ki. A csonteltérések detektálásának és követésének legegyszerúbben elérhető módszere a konvencionális röntgenvizsgálat. Az újonnan diagnosztizált myelomás betegek $80 \%$-ában már jelen van röntgennel kimutatható laesio; a leggyakrabban érintett csontok a gerincoszlop (65\%), a bordák (45\%), a koponya $(40 \%)$, a medence (30\%) és a hosszú csöves csontok (25\%). A lehetséges eltérések: a csont belső corticalis rétegének elvékonyodása, a lyticus laesiók és az úgynevezett „molyrágta” mintázat. A röntgenvizsgálat hátránya a viszonylag alacsony szenzitivitás, amely azzal magyarázható, hogy csontszerkezeti változás csak akkor detektálható, ha már a trabecularis csont 30\%-a károsodott [25]. Az új ajánlások mindinkább a röntgennél fejlettebb képalkotó metodikák felé mozdulnak el. A CT szenzitivitása - különösen az axiális csontok esetében - meghaladja a röntgenét, alkalmas kisebb csontlaesiók detektálására csakúgy, mint az ossealis és extraossealis plasmocytomák kimutatására. A nagy sugárterhelést kiküszöbölendő dolgozták ki újabban az úgynevezett alacsony dózisú (low dose) teljestest-CT-protokollokat, amelyek különösen alkalmasak a lyticus folyamatok diagnosztizálására [26]. Az MRI pontos képet ad az esetleges gerincvelői és idegi kompresszióról, a lágyrész-infiltrációkról, valamint a csontvelő myelomás infiltrációjáról, viszont a mineralizáció mértékét a CT-hez képest kevésbé jól jelzi. A csontvelő-infiltráció mintázata háromféle lehet: fokális, diffúz, valamint kevert. A negatív röntgenlelettel rendelkező myelomás betegek felében MRI-vel már kimutatható csonteltérés, amely többnyire fokális laesio. A PET-CT az MRI-hez hasonló szenzitivitású módszer a csontlaesiók detektálásában, ám a csontvelői infiltráció megítélésére kevésbé alkalmas. Hasznos lehet viszont a myelomás eltérések viabilitásának, azaz a terápia (például őssejt-transzplantáció) sikerességének megítélésében [27].

Fontos része az új ajánlásnak, hogy korábban smouldering myelomának nevezett esetekben (10-60\% plazmasejtarány és 100 alatti FLC-arány, nincs CRAB) MRI-t kell végezni, és több mint egy, myelomával összefüggő fokális laesio esetén MM a diagnózis, és kezelés indikált. $\mathrm{Az}$ ajánlás az MRI ismétlését javasolja, amennyiben az összefüggés nem bizonyított. Érdekes, hogy a myelomában rosszabb prognózist jelentő diffúz csontvelői infiltráció nem került be az ajánlásba, ennek oka a jelenség aspecifikus volta [3].

\section{Kezelés}

A myeloma kezelésének célja a lehető leghosszabb túlélés elérése úgy, hogy a beteg életminősége ezenközben a lehetô legjobb legyen. Cél tehát egyrészről a myeloma szövődményeinek (csonttörések, veseelégtelenség) megelőzése, másrészt a kezeléssel járó mellékhatások csökkentése. A megfelelő kezelésről való döntés mindig az adott beteg klinikai állapotától és személyes preferenciáitól függ, de a lehetőségeknek jelenleg Magyarországon leginkább határt szabó tényező az, hogy az OEP mit finanszíroz. A klinikai vizsgálatokban való részvétel ezért

3. táblázat | Az ISS- és R-ISS-kritériumrendszer (Palumbo és mtsai alapján [24])

\begin{tabular}{|c|c|c|c|c|c|}
\hline \multicolumn{3}{|l|}{ ISS } & \multicolumn{3}{|l|}{ R-ISS } \\
\hline Stádium & Kritérium & 5 éves PFS és OS* & Stádium & Kritérium & 5 éves PFS és OS* \\
\hline 1. & $\begin{array}{l}\text { Szérum-béta- } 2 \text {-mikroglobulin } \\
<3,5 \mathrm{mg} / 1 \text { és szérumalbumin } \\
>35 \mathrm{~g} / 1\end{array}$ & $49 \%$ és $77 \%$ & 1. & $\begin{array}{l}\text { ISS } 1+ \\
\text { FISH normális + } \\
\text { LDH normális }\end{array}$ & $55 \%$ és $82 \%$ \\
\hline 2. & $\begin{array}{l}\text { Sem az 1., sem a 3. stádium } \\
\text { kritériumainak nem felel meg }\end{array}$ & $36 \%$ és $62 \%$ & 2. & $\begin{array}{l}\text { Sem az 1., sem a } 3 . \\
\text { stádium kritériumainak } \\
\text { nem felel meg }\end{array}$ & $36 \%$ és $62 \%$ \\
\hline 3. & $\begin{array}{l}\text { Szérum-béta-2-mikroglobulin } \\
>5,5 \mathrm{mg} / 1\end{array}$ & $30 \%$ és $47 \%$ & 3. & $\begin{array}{l}\text { ISS } 3+ \\
\text { FISH vagy } \\
\text { LDH abnormális }\end{array}$ & $24 \%$ és $40 \%$ \\
\hline
\end{tabular}

*PFS és OS az egyes ISS- és R-ISS-alcsoportokban 11 klinikai vizsgálat 4445 betege alapján.

ISS = International Staging System; R-ISS = Revised International Staging System. 
aztán majdnem mindig óriási előny a beteg számára, hiszen így másképp még nem elérhető kezelésekhez juthat hozzá.

\section{Általános megfontolások}

Nem minden myelomás beteget kell kezelni, kezelés csak a 2. táblázatban felsorolt kritériumok [3], azaz a CRABkritériumrendszer szerinti tünetek vagy az új biológiai markerek (60\% feletti csontvelői plazmasejtarány, a 100 feletti könnyưlánc-arány és az egynél több myelomás laesio MRI-vel vizsgálva) fennállása esetén szükséges. Szintén nagy figyelmet igényel a rapidan emelkedő M-protein-szint (két hónapon belül duplázódik): a legtöbben egyetértenek abban, hogy - fóleg relapsuskor - ez kezelési indikáció.

Lehetôleg még a kezelés előtt történjen Pneumococcus, Meningococcus, Haemophilus, valamint évente influenza elleni oltás.

Kezelés előtt a betegeket kellően tájékoztatni kell, az ehhez javasolt betegtájékoztató remélhetóleg hamarosan letölthető a Magyar Onkohematológiai Betegekért Alapítvány (MOHA) honlapjáról (http://www.onkohemat. hu/). Javasolt felhívni erre vagy más hasonló civil szervezetre a betegek figyelmét, mivel sokan igénylik, hogy a kórháztól független forrásból is tájékozódhassanak betegségükről.

Tekintettel a betegség bonyolultságára, tüneteinek szerteágazó voltára - amik kiemelik a szokásos hematológiai betegségek közül, és kihívássá teszik a myelomás betegek gondozását -, a nemzetközi guideline-okkal egyetértésben a szerzők is fontosnak tartják, hogy ahol csak megoldható, a myelomás betegekkel erre szakosodott szakrendelésen foglalkozzanak. Így a betegeket myeloma iránt érdeklődő, a myelomás betegek gyógyítása irányában elkötelezett csapat gyógyítja, akik így több tapasztalatot tudnak szerezni az újabb kezelési és diagnosztikus lehetőségekkel, valamint a csak „egyedi méltányossággal" elérhető gyógyszerekkel, illetve a klinikai vizsgálatokkal. A szaktudás és a kezelési lehetőségek ilyen koncentrációja óriási túlélési előnyt jelenthet a betegek számára.

Az utóbbi évtizedekben számos új gyógyszercsoport jelent meg, és ezeknek sok képviselője már a gyakorlatban is elérhető myelomában, jelentős részben kiváltva a korábbi évekre jellemző kemoterápia-alapú kezelést. Ennek haszna a kezelés eredményességének növekedése és a toxicitás csökkenése. Ezeket a készítményeket általában „új szerek” néven emlegeti a szakirodalom.

\section{Új szerek}

Az első új szer a thalidomid volt, az imidek (más néven immunmoduláns szerek) csoportjának első tagja. Az 1990-es évek kezdetén anti-angiogenikus tulajdonságai miatt kezdték vizsgálni különböző tumorokban, köztük myelomában. A 2000-es évek elejétől a myeloma kezelé- sének bázisává vált, kiszorítva a korábbi VAD (vincristin, doxorubicin, dexamethason) kezelést [28].

Tekintettel súlyos neuropathiát okozó tulajdonságára, azonnal megindult a második generációs imidek kutatása. Az FDA 2006-ban, az EMA 2007-ben törzskönyvezte a lenalidomidot (Revlimid), amely hatékonyabb, mint a thalidomid, és kedvezőbb mellékhatás-profillal bír. Sajnos Magyarországon mind a mai napig nincs rá támogatás, csak egyedi méltányosság alapján lehet kérvényezni. Ezenközben az FDA és az EMA már befogadta a következő, kicsivel még hatékonyabb utódot, a pomalidomidot (Imnovid), amelynek indikációja a megelőző bortezomib- és lenalidomidkezelés utáni második relapsus. A pomalidomidnak fontos tulajdonsága, hogy a nagy rizikót jelentő t $(4 ; 14)$ és del(17p) laesióktól függetlenül hatékony lehet.

Az imidek mind tablettás formában vannak forgalomban, mellékhatásprofiljuk kedvező, fontos viszont, hogy a mélyvénás thrombosis fokozott rizikója miatt antikoagulálni szükséges mellettük a betegeket. Általában kortikoszteroidokkal, alkilálószerekkel (cyclophosphamid, melphalan) vagy egyéb új szerekkel kombináljuk óket, legalábbis az első ciklusokban, ami növeli a hatékonyságukat. Az ajánlás szerint a lenalidomidot és a pomalidomidot relapsusban fenntartó kezelésként kell alkalmazni a progresszióig.

A bortezomib (Velcade) az első proteoszómainhibitor (PI), 2005-ben lett törzskönyvezve myelomában [29]. Hatásának alapja a számos B-sejtes tumorban alapvető fontosságú NFkB-rendszer gátlása, de a pontos mechanizmus összetettebb ennél, és máig sem tisztázott minden részlete [30]. Kezdetben iv. monoterápiában lett törzskönyvezve, de az idők folyamán finomodott az ajánlás, jelenleg általában hármas kombinációk részeként, kortikoszteroiddal, sc. formában adjuk [31]. A magyar gyakorlatban a myeloma kezelésének gerince [32].

A bortezomib sikerét számos új PI megjelenése követte, ezek közül a carfilzomib (Kyprolis) kiváló mellékhatásprofiljával és rendkívüli hatékonyságával válik ki, nemrégiben nyert európai törzskönyvet [33]. Az ixazonib az első orálisan alkalmazható PI, ígéretes szer, amely könynyű alkalmazhatósága és kedvező mellékhatásprofilja miatt fenntartó kezelésként is használható.

Sok évvel az anti-CD20 rituximab sikere után B-sejtes lymphomákban, végre myelomában is megjelentek a hatékony antitestek. Jelenleg csak klinikai vizsgálatokban érhetők el, de a jövőben, remélhetőleg, myelomaellenes fegyvertárunk részei lesznek. Jelenleg Magyarországon is folynak klinikai vizsgálatok egy CD38 elleni antitest, a daratumumab hatékonyságával kapcsolatban, amely relapsusban monoterápiában alkalmazva rendkívül ígéretesnek tünt [34]. Az elotuzumab (anti-CS1/SLAMF7) kombinációban kiváló 32,5 hónapos PFS-t tudott elérni, a fázis 3 vizsgálatokat hamarosan publikálják [35].

A PD-1-gátlók az MM-sejtek immunrendszert blokkoló hatását antagonizálják; nagyon ígéretes gyógyszercsoport [36]. 
Az új és még újabb szerek listája végtelen; a fentiek azok, amelyekkel kapcsolatban várható, hogy az elkövetkező években a magyar betegek számára hozzáférhetők lesznek.

\section{Javasolt protokollok elsö vonalban}

Hagyományosan a myeloma indukciós kezelését két részben szokás tárgyalni: külön csoportban a transzplantálható korú (általában 65-70 év alatti, fitt betegek) és az ennél idősebb vagy súlyos komorbiditások miatt transzplantációra nem alkalmas betegeket. Az idősebbeknek szánt protokollokban jellemzően kisebb a szteroiddózis, a fiatalabb betegeknek őssejtgyứjtés előtt nem adható melphalan. Máskülönben az újabb protokollok általában mindkét korcsoportban múködnek, és nem annyira a transzplantációnál alkalmazott életkori határ, hanem a beteg fittsége az, ami a dózisredukciót irányítja. A legfontosabb üzenet, hogy a myeloma kezelését lehetóleg sohase kezdjük legalább egy új szer alkalmazása nélkül (1A), és hogy háromtagú kombinációk alkalmazása javasolt [1].

A magyar gyakorlatban a legtöbb, transzplantációra szánt beteg általában VTD- [37], VCD- [38] vagy PAD[39] kezelést kap, a VTD-t és PAD-ot lA szintü, a VCD-t 2B szintû evidenciák támogatják első vonalban $[1]$. Az IFM (Intergroupe Francophone du Myélome) jelenleg folytat egy prospektív, randomizált összehasonlítást a VTD- és a VCD-kezelés között, de retrospektív analízisek alapján valószínű, hogy a VTD a hatékonyabb, bár a neuropathiás szövődmény is itt gyakoribb [40]. A szerzók saját gyakorlatukban a PAD-ot preferálják extramedullaris myelomában, plazmasejtes leukaemiában, a VCD-t idősebb betegben vagy neuropathia fennállása vagy rizikója (például amyloidosis) esetén, egyébként pedig a VTD-t tartják a leghatékonyabbnak, de alapvetően bármelyik hármas bortezomidkombináció kiváló indukciós kezelés.

Sajátos magyar szempont, hogy míg a bortezomib gyakorlatilag szabadon hozzáférhető, addig a protokoll részét képező többi szer beszerzése nehézkes. A legtöbb protokollban szereplő orális dexamethason nálunk nincs forgalomban, helyette általában metilprednisolont adunk, esetleg iv. alkalmazzuk. A cyclophosphamid (Endoxan) pár éve elvesztette támogatottságát, általános indikációban írható fel, a melphalan (Alkeran), a thalidomid és a lenalidomid csak egyedi méltányossági kérvényekkel szerezhető be, amely többhetes időveszteséggel és jelentős adminisztratív teherrel jár.

Evidencia támogatja a FISH-eredmények használatát a terápia meghatározásánál: vannak alcsoportok, amelyek imidekre (hiperdiploid) és vannak, amelyek bortezomibra [t(4;14) és kisebb mértékben del(17p)] reagálnak jobban $[39,41]$.

Fontos, hogy a kezelés ne valamely ciklusszámig, hanem a legjobb válasz eléréséig folytatódjon. A szubopti- mális válasz kérdését a monitorozás szakaszban tárgyaljuk.

A magyar gyakorlatban idősebb betegek esetében is általában hármas kombináció a preferált: a kombináció tagja legyen egy új szer (thalidomid vagy bortezomib), kortikoszteroid és egy alkilátor (cyclophosphamid vagy melphalan). A választás részben a betegség jellegén múlik (bizonyos FISH-eredmények, illetve veseelégtelenség esetén bortezomibbázisú kezelés a jó választás), részben viszont a beteg általános állapotán, mobilitásán és preferenciáján. Kevésbé mobilis beteg esetében nehézséget okozhat a bortezomibinjekciók beadása, egyszerúbb a tablettás protokollok adása. Lehetséges kombinációk a CTD és MPT, illetve a VCD és MPV. Az MPT- és MPVkezeléseket lA szintü evidenciák támogatják [1], ennek ellenére sok szerző van azon a véleményen, hogy két alkilálószer közül a melphalan standard dózisa ugyan talán minimálisan hatékonyabb, mint a cyclophosphamid, de ezt az utóbbi jobb tolerálhatósága bőven kompenzálja. A VTD ebben a betegpopulációban kevésbé jól múködött, ennek az lehet a magyarázata, hogy ez a kombináció nagy dózisú melphalannal együtt igazán hatékony.

Idősebb betegnél fontos a megfelelő dózisredukció, ehhez az IMWG kalkulátora (http://www.myelomafrailtyscorecalculator.net/) és Palumbo professzor cikkei adhatnak segítséget [42]. Általában helyes gyakorlat sürgős kezelés esetén (például veseelégtelenségben) a kezdeti párhetes agresszívabb kezelés után az intenzitás csökkentése (a kortikoszteroid dózisának csökkentése, a bortezomib heti egyszeri adására való áttérés), mert ezzel a beteget tovább tarthatjuk a kezelésen és összességében nagyobb dózis adható be. Ha a kezelés kevésbé sürgető, akkor az is lehetséges opció, hogy elemenként, lassan építjük fel, hogy hozzászoktassuk a beteget a gyógyszerekhez és megelőzzük a mellékhatások miatti kényszerszünetet. Idősebb betegnél a toxicitásprofil szempontjából ideális indukciós kezelés volna a lenalidomid és kis dózisú szteroidkombináció (2B) [43], de a fentebb említett problémák miatt ez hazánkban jelenleg nem jön szóba.

Fenntartó kezelés a Magyarországon erre a célra egyedül szóba jövő thalidomiddal nem javasolható általánosságban, de a helyzet változhat, ha megoldódik a lenalidomid finanszírozása, aminek az alkalmazását több tanulmány támogatja $(1 \mathrm{~A} / 2 \mathrm{~B})$. Mindazonáltal pár hónapos thalidomidkonszolidáció megfontolható, hogy egy kevésbé jó választ VGPR/CR-be transzformáljunk. Nagy rizikójú myelomában kombinált, bortezomibbázisú fenntartó kezeléssel vannak biztató eredmények [39].

A fenti protokollokat a 4. táblázat foglalja össze [37$39,43-55]$.

\section{Transzplantáció}

A csontvelő-transzplantáció a 65-70 éves kor alatti betegeknél az 1980-as, 1990-es évek óta standard kezelés. Ebből az időból származnak azok a vizsgálatok, amelyek 
4. táblázat | Myelomában alkalmazható protokollok, PFS és OS első vonalban való alkalmazás esetén

\begin{tabular}{|c|c|c|c|c|c|}
\hline Protokoll & Összetevôk & Dózis & Kezelés napjai & Ciklushossz & $\begin{array}{l}\text { Hivatkozás, hatékonyság első } \\
\text { vonalban }\end{array}$ \\
\hline \multirow[t]{3}{*}{ VTD } & Bortezomib & $1,3 \mathrm{mg} / \mathrm{m}^{2} \mathrm{sc}$ & 1., 4., 8., 11. & 3 hét & $\begin{array}{l}\text { Rosiñol et al., Blood, } 2012 \\
\text { [37] }\end{array}$ \\
\hline & Thalidomid & 100-200 mg p.o. & naponta & & $\begin{array}{l}\text { PFS 56,2 hónap, } 3 \text { éves OS } \\
74 \% *\end{array}$ \\
\hline & Dexamethason & 20 mg p.o. & $1-2 ., 4-5 ., 8-9 ., 11-12$. & & \\
\hline \multirow[t]{4}{*}{ VRD } & Bortezomib & $1,3 \mathrm{mg} / \mathrm{m}^{2} \mathrm{sc}$ & 1., 4., 8., 11. & 3 hét & $\begin{array}{l}\text { Richardson et al., Blood, } 2010 \\
\text { [44] }\end{array}$ \\
\hline & Lenalidomid & 25 mg p.o. & $1-14$ & & $\begin{array}{l}18 \text { hónapos PFS } 75 \%, 18 \\
\text { hónapos OS 97\% }\end{array}$ \\
\hline & Dexamethason & $40 \mathrm{mg}$ p.o. & $1 ., 8 ., 15$ & & \\
\hline & & vagy 20 mg p.o. & $1-2 ., 4-5 ., 8-9 ., 11-12$. & & \\
\hline \multirow[t]{3}{*}{ PAD } & Bortezomib & $1,3 \mathrm{mg} / \mathrm{m}^{2} \mathrm{sc}$ & $1 ., 4 ., 8 ., 11$. & 3 hét & $\begin{array}{l}\text { Sonneveld et al., J. Clin Oncol., } \\
2012 \text { [39] }\end{array}$ \\
\hline & Adriamycin & $9 \mathrm{mg} / \mathrm{m}^{2}$ iv. & $1-4$ & & PFS 35 hónap, 3 éves OS 61\% \\
\hline & Dexamethason & 40 mg p.o. & $\begin{array}{l}1-4 . \text { (8-11. és } 15-18 . \text { csak az első } \\
\text { ciklusban) }\end{array}$ & & \\
\hline \multirow[t]{3}{*}{$\begin{array}{l}\text { CyBorDex } \\
\text { (VCD) }\end{array}$} & Cyclophosphamid & $\begin{array}{l}300 \mathrm{mg} / \mathrm{m}^{2} \text { vagy } \\
500 \mathrm{mg} \text { p.o. }\end{array}$ & $1 ., 8 ., 15 .,(22)$. & 3-4 hét & $\begin{array}{l}\text { Reeder et al., Leukemia, } 2009 \\
\text { [38] }\end{array}$ \\
\hline & Bortezomib & $1,3 \mathrm{mg} / \mathrm{m}^{2} \mathrm{sc}$ & 1., 4., 8., 11. vagy 1., 8., 15., 22. & & 5 éves PFS 42\%, OS 70\% \\
\hline & Dexamethason & $20-40 \mathrm{mg}$ p.o. & $\begin{array}{l}1-2 ., 4-5 ., 8-9 ., 11-12 . \text { vagy } \\
1-4 ., 8-11 ., 15-18 .\end{array}$ & & \\
\hline \multirow[t]{3}{*}{ MPV } & Melphalan & 6-9 mg/m² p.o. & $1-4$ & 6 hét & $\begin{array}{l}\text { San Miguel et al., N. Engl. J. } \\
\text { Med., } 2008 \text { [45] }\end{array}$ \\
\hline & Bortezomib & $1,3 \mathrm{mg} / \mathrm{m}^{2} \mathrm{sc}$ & $\begin{array}{l}\text { 1., } 8 ., 22 ., 29 . ; \text { esetleg az elsó } \\
\text { ciklusban heti } 2 \times \text {, azaz 1., 4., 8., } \\
11 ., 22 ., 25 ., 29 ., 32 .\end{array}$ & & $\begin{array}{l}\text { PFS } 21,7 \text { hónap, } 3 \text { éves OS } \\
68,5 \%\end{array}$ \\
\hline & Prednisolon & $40 \mathrm{mg} / \mathrm{m}^{2}$ p.o. & $1-4$ & & \\
\hline \multirow[t]{3}{*}{$(\mathrm{C}) \mathrm{TD}(\mathrm{a})$} & (Cyclophosphamid) & 500 mg p.o. & 1., 8., 15., (22.) & $\begin{array}{l}3 \text { vagy } 4 \\
\text { hét }\end{array}$ & $\begin{array}{l}\text { Morgan, Clin. Cancer Res., } \\
2013 \text { [46] }\end{array}$ \\
\hline & Thalidomid & $\begin{array}{l}(50-) 100-200 \\
\text { mg p.o. }\end{array}$ & folyamatosan & & $\begin{array}{l}\text { CTD: PFS } 26 \text { hónap, } 3 \text { éves } \\
\text { OS } 71 \%\end{array}$ \\
\hline & Dexamethason & (20-) 40 mg p.o. & $\begin{array}{l}1-4 \text {. és } 11-15 \text {. (vagy } 1-4 \text {. és } \\
15-18 \text {.) }\end{array}$ & & $\begin{array}{l}\text { csökkentett intenzitású változat } \\
\text { (CTDa): } 4 \text { hetes ciklusokban } \\
\text { kisebb thalidomid- és } \\
\text { szteroiddózissal }\end{array}$ \\
\hline \multirow[t]{3}{*}{ MPT } & Melphalan & $4 \mathrm{mg} / \mathrm{m}^{2}$ p.o. & $1-7$ & 6 hét & Facon et al., Lancet, 2007 [47] \\
\hline & Prednisolon & $40 \mathrm{mg} / \mathrm{m}^{2}$ p.o. & $1-7$ & & $\begin{array}{l}\text { PFS } 27,5 \text { hónap, } 3 \text { éves OS } \\
51,6 \%\end{array}$ \\
\hline & Thalidomid & 100 mg p.o. & folyamatosan & & \\
\hline \multirow[t]{3}{*}{ (C)RD } & (Cyclophosphamid) & 500 mg p.o. & $1 ., 15$. & 4 hét & $\begin{array}{l}\text { Rajkumar et al., Lancet Oncol., } \\
2010[43]\end{array}$ \\
\hline & Dexamethason & 20-40 mg p.o. & $\begin{array}{l}1-4 . \text { és } 15-18 . \text { vagy } 1 ., 8 ., 15 ., \\
22 .\end{array}$ & & $\begin{array}{l}\text { RevDex: PFS } 25,3 \text { hónap, } \\
3 \text { éves OS } 74 \%\end{array}$ \\
\hline & Lenalidomid & $25 \mathrm{mg}$ p.o. & 1-21., majd egy hét szünet & & \\
\hline BTD & Bendamustin & $60-90 \mathrm{mg} / \mathrm{m}^{2}$ iv. & 1. és 8. (vagy 1-2.) & 4 hét & $\begin{array}{l}\text { Grey-Davies et al., Br. J. } \\
\text { Haematol., } 2012 \text { [48] (BTD) }\end{array}$ \\
\hline \multirow[t]{3}{*}{ és BLD } & Thalidomid (BTD) & 50-200 mg p.o. & naponta & & $\begin{array}{l}\text { Lentzsch et al., Blood, } 2012 \\
\text { [49] (BLD) }\end{array}$ \\
\hline & $\begin{array}{l}\text { vagy Lenalidomid } \\
(\mathrm{BLD})\end{array}$ & 10 mg p.o. & $1-21$ & & \\
\hline & Dexamethason & 40 mg p.o. & 1., 8., 15., 22 . & & \\
\hline
\end{tabular}


A 4. táblázat folytatása

\begin{tabular}{|c|c|c|c|c|c|}
\hline Protokoll & Összetevők & Dózis & Kezelés napjai & Ciklushossz & $\begin{array}{l}\text { Hivatkozás, hatékonyság első } \\
\text { vonalban }\end{array}$ \\
\hline \multirow[t]{3}{*}{ KCD (CCyD) } & Carfilzomib & $\begin{array}{l}36 \mathrm{mg} / \mathrm{m}^{2} \text { iv. }(\mathrm{az} \\
\text { 1. ciklusban } 20 \\
\left.\mathrm{mg} / \mathrm{m}^{2}\right)\end{array}$ & 1., 2., 8., 9., 15., 16. & 4 hét & $\begin{array}{l}\text { Bringhen et al., Blood, } 2014 \\
\text { [50] }\end{array}$ \\
\hline & Cyclophosphamid & $300 \mathrm{mg} / \mathrm{m}^{2}$ p.o. & $1 ., 8 ., 15$. & & \multirow{2}{*}{$\begin{array}{l}\text { Nem ASCT kandidátus betegek } \\
\text { esetében } 2 \text { éves PFS } 76 \text {, } \\
\text { OS } 87 \%\end{array}$} \\
\hline & Dexamethason & 40 mg p.o. & $1 ., 8 ., 15 ., 22$. & & \\
\hline \multirow[t]{3}{*}{ KRD } & Carfilzomib & $\begin{array}{l}27 \mathrm{mg} / \mathrm{m}^{2} \text { iv. }(\mathrm{az} \\
\text { 1. ciklusban } 20 \\
\left.\mathrm{mg} / \mathrm{m}^{2}\right)\end{array}$ & 1., 2., 8., 9., 15., 16. & 4 hét & \multirow[t]{3}{*}{$\begin{array}{l}\text { Stewart et al., N. Engl. J. Med., } \\
2015 \text { [51] }\end{array}$} \\
\hline & Lenalidomid & 25 mg p.o. & 1-21., majd egy hét szünet & & \\
\hline & Dexamethason & 40 mg p.o. & $1 ., 8 ., 15 ., 22$. & & \\
\hline \multirow{3}{*}{$\begin{array}{l}\text { Ixazonib- } \\
\text { lenalidomid- } \\
\text { dexamethason }\end{array}$} & Ixazonib & 4 mg p.o. & 1., 8., 15., majd egy hét szünet & 4 hét & \multirow[t]{3}{*}{$\begin{array}{l}\text { Kumar et al., Lancet Oncol., } \\
2014 \text { [52] }\end{array}$} \\
\hline & Lenalidomid & 25 mg p.o. & 1-21., majd egy hét szünet & & \\
\hline & Dexamethason & 40 mg p.o. & 1., 8., 15., 22 . & & \\
\hline \multirow{2}{*}{$\begin{array}{l}\text { Pomalidomid- } \\
\text { dexamethason } \\
\text { (Pom/Dex) }\end{array}$} & Pomalidomid & 4 mg p.o. & $1-21$ & 4 hét & \multirow[t]{2}{*}{$\begin{array}{l}\text { Richardson et al., Blood, } 2014 \\
\text { [53] }\end{array}$} \\
\hline & Dexamethason & 40 mg p.o. & $1 ., 8 ., 15 ., 22$. & & \\
\hline \multirow[t]{5}{*}{ EDAP } & Etoposid & $100 \mathrm{mg} / \mathrm{m}^{2} \mathrm{iv}$ & 1-4. folyamatos infúzió & 3-4 hét & \multirow[t]{5}{*}{$\begin{array}{l}\text { Barlogie et al., J. Clin. Oncol., } \\
1989 \text { [54] }\end{array}$} \\
\hline & Cisplatin & $20 \mathrm{mg} / \mathrm{m}^{2}$ iv. & 1-4. folyamatos infúzió & & \\
\hline & Dexamethason & $40 \mathrm{mg}$ iv./p.o. & $1-5$. & & \\
\hline & ARA-C & $1000 \mathrm{mg} / \mathrm{m}^{2}$ iv. & 5. & & \\
\hline & GCSF, hidrálás & & & & \\
\hline \multirow[t]{8}{*}{ (V)DT-PACE } & (Bortezomib) & $1,3 \mathrm{mg} / \mathrm{m}^{2} \mathrm{sc}$ & $1 ., 4 ., 8 ., 11$. & 4 hetente & $\begin{array}{l}\text { Barlogie et al., Br. J. } \\
\text { Haematol., } 2007 \text { [55] }\end{array}$ \\
\hline & Dexamethason & 40 mg p.o. & $1-4$. & & \\
\hline & Thalidomid & $200-400$ mg p.o. & folyamatosan & & \\
\hline & Cisplatin & $10 \mathrm{mg} / \mathrm{m}^{2} \mathrm{iv}$ & 1-4. folyamatos infúzió & & \multirow{5}{*}{$\begin{array}{l}\text { (az alkalmazott gyógyszer } \\
\text { típusától függóen mehetnek } \\
\text { együtt } 1 \text { vagy } 2 \text { infúzióba) }\end{array}$} \\
\hline & Adriamycin & $10 \mathrm{mg} / \mathrm{m}^{2}$ iv. & 1-4. folyamatos infúzió & & \\
\hline & Cyclophosphamid & $400 \mathrm{mg} / \mathrm{m}^{2}$ iv. & 1-4. folyamatos infúzió & & \\
\hline & Etoposid & $40 \mathrm{mg} / \mathrm{m}^{2}$ iv. & 1-4. folyamatos infúzió & & \\
\hline & GCSF, hidrálás & & & & \\
\hline \multirow[t]{2}{*}{ MP } & Melphalan & $4 \mathrm{mg} / \mathrm{m}^{2}$ p.o. & $1-7$. & 6 hét & \\
\hline & Prednison & $40 \mathrm{mg} / \mathrm{m}^{2}$ p.o. & $1-7$ & & \\
\hline
\end{tabular}

*PFS (hónapokban) és OS (3 éves \%). A megadott adatok a hivatkozott elsővonalbeli fázis 3 vizsgálatok eredményei. Fontos, hogy a vizsgált kohorszok különbözősége miatt ez csak referenciaként szolgál, az egyes protokollok összehasonlítására nem alkalmas.

a nagy dózisú melphalan ASCT létjogosultságát megalapozták, és ekkor sikerült először legalább a fiatalabb myelomás betegek túlélésében jelentős javulást elérni [56].

Főleg amerikai centrumok vezették be, hogy a kis rizikójú betegeik a nagy rizikójúaktól eltérő kezelésben részesülnek. A Mayo Klinika MSMART algoritmusa alapján például az ilyen betegeket bortezomib nélkül, imidbázisú kombinációval kezelik, és őket sokszor csak második remisszióban transzplantálják [57]. Az ezzel kapcsolatos nagy, randomizált vizsgálatok eredményeit pár éven belül fogják publikálni. Saját kutatásunk, más retrospektív vizsgálatokkal egyetértésben, nem mutatott OS-különbséget a korai és a halasztott ASCT-k között [58]. Sok praktikus szempont (fiatalabb életkor, könynyebb őssejtgyưjtés kevesebb kemoterápia után, őssejttárolás kapacitása és költségei) szól az első vonalban való átültetés mellett [59]. Mindezek alapján az európai állás- 
pont (az ESMO és a szerzők álláspontja) az, hogy minden betegnek a számára legjobb lehetséges kezelést kell adni, hiszen az új szerek megjelenéséből elsősorban a jó prognózisú betegek profitáltak, ami jelenlegi tudásunk szerint lehetőleg több új szert tartalmazó kombinált indukciót és első vonalban végzett autológ átülttetést jelent (1A).

A második transzplantáció kérdése bonyolultabb, és nem is csak szorosan vett orvosszakmai, hanem részben finanszírozási és kapacitási kérdés. Egy prospektív, randomizált vizsgálat hasonlította össze a második transzplantációt standard dózisú kemoterápiával és fenntartó kezeléssel, és - legalábbis a PFS tekintetében - egyértelműen a transzplantációt hozta ki győztesnek (PFS 19 és 11 hónap) [60]. Ennek alapján azokban a betegekben, akiknél az első transzplantáció jól múködött (2 évnél hosszabb remisszió) és jól reagáltak a relapsus kezelésére, de kifejezett mellékhatások (elsősorban neuropathia) jelentkeztek, megfontolható a második beavatkozás.
Az allogén transzplantáció, noha az újabb technikákkal a mortalitás $10 \%$ alá szorult [61], továbbra sem standard kezelés myelomában, fiatal, nagy rizikójú betegek esetében jöhet esetleg szóba (2B).

\section{Monitorozás a kezelés során és utána}

A kezelésre adott választ általában az M-protein-szint csökkenése jelzi, könnyúlánc-myelomában a szérumkönnyúlánc-szint (vagy ha ez nem elérhető, akkor a vizelet Bence-Jones-fehérje mennyiségének) változása. Ezeket a vizsgálatokat minden ciklus után javasolt elvégezni. Nonszekretoros myelomában a csontvelő vizsgálatára, extramedullaris myelomában a képalkotókra (MRI, esetleg PET) kell hagyatkoznunk. Ezek alapján lehet a beteg válaszát az sCR, CR, VGPR, PR kategóriák valamelyikébe besorolni (5. táblázat) [62].

Ismert, hogy a mélyebb válasz általában hosszabb PFS-t jelez előre, de egyelőre nem világos, hogy szuboptimális válasz (platófázis PR-ben) esetén indokolt-e a

5. táblázat | Válaszkritériumok az IMWG szerint (Rajkumar és mtsai, 2011) [62]

\begin{tabular}{|c|c|}
\hline Válasz & IMWG-kritérium \\
\hline Molekuláris CR & CR plusz negatív ASO-PCR ( $10^{-5}$ szenzitivitással) \\
\hline Immunfenotípusos CR & $\begin{array}{l}\text { sCR plusz klonális plazmasejtek hiánya > } 4 \text { színú áramlási citométerrel minimum } 1 \text { millió csontvelői } \\
\text { sejtet számlálva }\end{array}$ \\
\hline Szigorú komplett válasz (sCR) & $\begin{array}{l}\text { CR, ezenfelül normális szabadkönnyúlánc- (FLC-) arány és a klonális plazmasejtek hiánya a } \\
\text { csontvelőben áramlási citometriával vagy immunhisztokémiával vizsgálva }\end{array}$ \\
\hline Komplett válasz (CR) & $\begin{array}{l}\text { Negatív szérum- és vizelet-immunfixáció, a korábbi lágyrész-plasmocytomák eltűnése és 5\% alatti } \\
\text { csontvelői plazmasejtarány }\end{array}$ \\
\hline Nagyon jó parciális válasz (VGPR) & $\begin{array}{l}\text { Csak immunfixációval észlelhető vagy 90\%-nál nagyobb mértékben csökkent szérum-M-protein, } \\
\text { vagy a vizelet-M-protein } 100 \mathrm{mg} / 24 \text { h alá csökkenése }\end{array}$ \\
\hline \multirow[t]{4}{*}{ Parciális válasz (PR) } & $\begin{array}{l}\text { Az M-protein mennyiségének legalább } 50 \% \text {-os csökkenése a szérumban és legalább 90\%-os vagy } 200 \\
\text { mg/24 h alá való csökkenése } 24 \text { órás gyűjtött vizeletben }\end{array}$ \\
\hline & $\begin{array}{l}\text { Ha a szérum-M-protein nem használható: legalább 50\% csökkenés az érintett és nem érintett FLC-k } \\
\text { különbségében }\end{array}$ \\
\hline & $\begin{array}{l}\text { Ha sem a szérum-M-protein, sem az FLC mérése nem használható, akkor legalább } 50 \% \text { csökkenés a } \\
\text { csontvelői plazmasejtarányban }\end{array}$ \\
\hline & Az előbbiek mellett, ha jelen volt, legalább $50 \%$-os csökkenés a plasmocytomák méretében \\
\hline \multirow[t]{3}{*}{$\begin{array}{l}\text { Minimális válasz }(\mathrm{MR}) \\
\text { (csak relabált betegeknél) }\end{array}$} & $\begin{array}{l}\text { Legalább } 25 \% \text {, de kevesebb, mint } 50 \% \text { csökkenés a szérum-M-proteinben, és a vizelet-M-protein } \\
50-89 \% \text {-os csökkenése }\end{array}$ \\
\hline & Ha jelen voltak, akkor 25-49\%-os csökkenés a lágyrész-plasmocytomák méretében \\
\hline & A lyticus laesiók nem növekednek \\
\hline Stabil betegség (SD) & Nem felel meg az egyéb kritériumoknak \\
\hline \multirow[t]{7}{*}{ Progresszív betegség (PD) } & 25\%-nál nagyobb emelkedés a legjobb mért válaszhoz képest az alábbiakban: \\
\hline & - Szérum-M-protein (legalább 5 g/l abszolút emelkedés) \\
\hline & - Vizelet-M-protein (legalább 200 mg/24 h abszolút emelkedés) \\
\hline & - Ha ez elóbbiek nem mérhetők: FLC-emelkedés (legalább 100 mg/l abszolút emelkedés) \\
\hline & - Csontvelői plazmasejtarány ( $10 \%$ feletti) \\
\hline & Új csontlaesiók megjelenése vagy a korábbiak növekedése \\
\hline & Mással nem magyarázható hypercalcaemia megjelenése \\
\hline
\end{tabular}


kezelés folytatása egy másik kombinációval vagy sem. A szerzők egyetértenek abban, hogy ha transzplantáció elótt az indukciós kezelés nem ér el legalább PR-t, akkor további kezelés indokolt. Szuboptimális válasznál a másik lehetőség az ASCT-t követő konszolidáció. Az MRD mérésére a magyar gyakorlatban az áramlási citometria lenne elsősorban alkalmas, de jelenleg erre még nincs beállítva megbízható, standardizált metodika.

A kezelés végeztével vagy transzplantáció után általában 2-3 havonta ajánlatos az M-protein- (könnyúlánc-) szinteket monitorozni. Az M-protein-szint emelkedése a remisszió végét jelzi, ilyenkor javasolt sûríteni a monitorozást, hogy megelőzzük az esetleges szövődményeket. A CR alátámasztására szükséges a csontvelővizsgálat megismétlése. Hasonlóan előírás a transzplantációt követő 100. napi csontvelőkontroll. Ugyancsak helyeselhető gyakorlat újabb kezelési vonalak előtt megismételni a szövettant és a FISH-vizsgálatot, mert egy újonnan megjelent FISH-eltérés befolyásolhatja a szóba jövő kezelési opciókat.

\section{Javasolt protokollok relapsusban}

$\mathrm{Az}$ első vonalbeli kezelésnél tárgyalt nehézségek még hatványozottabban jelentkeznek relapsusban. A beteg ekkorra idősebb, a kezelési lehetőségek egy részét kimerítette, mások a korábbi kezelések szövődményei (például neuropathia) miatt nem alkalmazhatóak. Itt is elsősorban a finanszírozási helyzet diktál. Szerencsés esetben a centrum tud ajánlani klinikai vizsgálatot, vagy tovább tudja irányítani a beteget oda, ahol ilyen elérhető.

Fontos különbség van a lassú, biokémiai relapsus, az M-protein-szint robbanásszerü emelkedése (rövid duplázódási idő) és a már eleve tünetesen relabáló beteg helyzete között. Míg az első esetben az obszerváció elfogadható, addig az utóbbi betegek kezelést igényelnek.

Lényeges szempont az is, hogy mi volt a beteg első kezelése. Ha az thalidomidalapú vagy más, bortezomibot nem tartalmazó kombináció, akkor viszonylag egyszerü a helyzet, bármelyik említett bortezomibbázisú kezelés jó választás.

Gyakoribb viszont, hogy a beteg első vonalbeli kezelése már a fentiek szellemében bortezomibbázisú volt. Ekkor nehezebb a helyzet. Ha nem használtunk még thalidomidot, akkor ennek kombinációi (CTD, MPT, esetleg bendamustinnal való kombináció) szóba jöhetnek, különösen, ha a FISH nem jelez kedvezőtlen prognózist. A másik lehetôség a bortezomib ismétlése lehetőleg a korábbitól eltérő hármas kombinációban.

Ideális relapsusszer a korábban már többször említett lenalidomid. Magas ára miatt mind a mai napig csak egyedi finanszírozással érhető el OEP-támogatással. A lenalidomid jól kombinálható dexamethasonnal (RevDex), cyclophosphamiddal és dexamethasonnal (CRD), illetve bortezomibbal és dexamethasonnal (VRD), majd platófázistól kezdve fenntartó kezelésként adható tovább. Amennyiben a betegség túlnő a platófázison (bio- kémiai progresszió), még mindig hatásos lehet a lenalidomid folytatása és a kiegészítő szerek újraindítása kicsit más kombinációban (például bendamustin és szteroid hozzáadása).

\section{Speciális helyzetek}

Könnyü láncok okozta heveny veseelégtelenségben nagy jelentősége volna a tartós high cut off dialízisnek, de hazánkban a dialíziscentrumok megfelelő finanszírozás hiányában nem tudják vállalni, pedig ez a módszer képes eltávolítani a könnyű láncokat.

A plazmasejtes leukaemia, az extramedullaris relapsus nagy kihívást jelent, a betegek agresszív kombinált kezelést igényelnek (például VDT-PACE), majd transzplantációt és bortezomib fenntartó kezelést. Mivel általában nagyon gyorsan bekövetkezik a relapsus, fiatalabb betegnél elért igen jó remisszióban szóba jöhet az allogén SCT is. A lehetőségekhez képest idősebb betegeknél is bortezomibbázisú kezelésre kell törekedni.

A központi idegrendszeri érintettség szerencsére ritka, nagyon nehezen kezelhető, mivel a szerek, amelyek ismerten átjutnak a vér-agy gáton, nem túl aktívak myelomában, pláne nem ebben a stádiumban. A bortezomib nem jelenik meg a liquorban (intrathecalisan beadva viszont halálos toxicitást okoz!), az imidek inkább bejutnak, kérdés, hogy hatnak-e [63].

Rezisztens betegségben szintén szóba jöhetnek olyan kemoterápiás salvage kombinációk, mint az EDAP vagy a (V)DT-PACE, de ezek általában rosszul toleráltak, ezért csak olyankor ajánlottak, ha nincs kevésbé toxikus alternatíva (például klinikai vizsgálat).

\section{Szupportí terápia}

\section{Biszfoszfonátok}

Ha nincs kontraindikációja, minden aktív myelomás beteg esetében indokolt iv. biszfoszfonátok alkalmazása. Nagy vizsgálatokból származó evidencia szól amellett, hogy az iv. zoledronat per os clodronattal összehasonlítva nemcsak szignifikánsan csökkentette a csonttörések gyakoriságát, hanem 6 hónapos túlélési előnyt is jelentett [46]. A kezelés legfontosabb szövődménye az osteonecrosis (ONJ), de ennek gyakorisága megfelelő betegoktatással és a kezelés megindítása előtti kötelező fogászati szüréssel csökkenthető.

A biszfoszfonátkezelés mellett kalcium-és D-vitaminkészítmények alkalmazandók. A biszfoszfonátok a kezelés után legalább két évig adandók, majd progressziókor ismét el kell indítani a kezelést. Súlyos osteoporosis és fracturák esetén megfontolható a két éven túli alkalmazás stabil remisszió esetén is, a betegek kényelme érdekében viszont lehet ritkítani a dózisokat.

Iv. biszfoszfonátkezelés mellett szükséges a vesefunkció monitorozása. Az IMWG ajánlása szerint $30 \mathrm{ml} /$ perc kreatininclearance alatt mind a zoledronat, mind a pamidronat kontraindikált, ugyanakkor van adat arra, hogy 
a pamidronat lassú infúzióban (maximum $20 \mathrm{mg}$ /óra) a szokásos dózisban alkalmazható $10 \mathrm{ml} /$ perc GFR felett [64].

\section{Sugárterápia és vertebroplastica}

A hatékony kemoterápiák miatt a sugárkezelés jelentősége visszaszorult, elsősorban a kemoterápia ellenére perzisztáló fájdalom képezi indikációját, illetve nagyobb plasmocytomás laesiók, mütéti stabilizációt igénylő csonttörések esetén jön szóba. Gerincvelő-kompressziót okozó lágyrész-tumor esetén sürgősséggel alkalmazható, lehetőleg szisztémás kezeléssel párhuzamosan.

A fájdalmas csigolyalaesiók másik lehetséges kezelési módja a vertebroplastica, illetve a kyphoplastica, amelyek során csontcementtel töltik fel az összeroppant, instabil csigolyát. Az előbbit az országban több helyen végzik.

\section{Eritropoetin, GCSF}

A kemoterápia, illetve csontvelő-infiltráció okozta anaemia a modern szerek mellett ugyan ritkábban okoz problémát, de ilyen esetben a transzfúzió jó és - a generikumok megjelenésével - olcsóbb alternatívája lehet az eritropoetin. Lenalidomidkezelés mellett, fóleg sokadik vonalban, probléma lehet a cytopenia, ilyenkor is lehetöség van eritropoetin, illetve GCSF adására, hogy folytatni tudjuk a terápiát.

\section{Profilaktikus antibiotikum és antivirális szerek}

A frissen diagnosztizált myeloma kezelésének első két hónapjában, különösen veseérintettség esetén, nagyon gyakoriak és nemritkán fatálisak az infekciók [65]. Jelenleg is zajlik a TEAMM study, amely a levofloxacinprofilaxis szerepét vizsgálja a modern kemoterápiák mellett. A szerzók véleménye szerint legalábbis nagy rizikójú betegekben az indukciós kezelés első hónapjaiban indokolt a profilaxis: a szóba jövő szerek a levofloxacin $(1 \times 500$ $\mathrm{mg})$ vagy az amoxicillin $(2 \times 500 \mathrm{mg})$, ám a hazai Clostridium-járvány aktuális állása gondolkozásunkat befolyásolhatja.

Valamennyi proteoszómainhibitor mellett aciclovirprofilaxis szükséges az övsömör nagy rizikója miatt, más esetekben az ajánlás csak relatív.

\section{Antikoaguláció}

Tekintettel az imidek thrombogen hatására, imidbázisú kombinált kemoterápia mellett általában profilaktikus dózisú LMWH alkalmazása szükséges. Több formula létezik, amely a betegeket kis és nagy rizikójú csoportokra osztja, például a brit myeloma guideline [66]. Nagy vonalakban a megelőző thromboticus esemény, az immobilizáció, a súlyos komorbiditás és a friss mütét indokolnak mindenképpen LMWH-t, míg ezek hiányában kis dózisú aszpirin is elfogadható. Ugyan a guideline-ok nem tartalmazzák, de logikus, hogy a magasabb életkor is thrombosisrizikó, s hogy a myeloma önmagában is, nemcsak imidkezelés esetén fokozza a thrombosisrizi- kót, tehát ha több rizikótényező is fennáll, akkor imidkezelés hiányában is indokolt lehet a kis dózisú LMWH.

\section{Következtetések}

Az utóbbi évtizedek kutatásainak eredményeként sokkal többet tudunk a myeloma biológiai hátteréről, és ez a tudás sok tekintetben beépült a gyakorlati betegellátásba is. Az új gyógyszerek megsokszorozták a betegek várható túlélési esélyét, az új vizsgálómódszerek pedig segítenek kiválasztani a leghatékonyabb kezelést minden beteg számára. A legújabb kezelésekkel korábban nem látott mélységú válaszok észlelhetők a betegek többségénél, és nem vagyunk messze attól, hogy a kezelés célja már myelomában is a gyógyulás legyen. Mindennek persze óriási költsége van, ezért noha számos kezelésről és vizsgálómódszerről tudjuk, hogy remekül használhatók myelomában, finanszírozásuk nem megoldott. Jelenleg a legnagyobb kihívás számunka talán éppen az, hogy megtaláljuk a módot arra, hogy az új kezelések Magyarországon is hamar hozzáférhetők legyenek.

Anyagi támogatás: A közlemény megírása anyagi támogatásban nem részesült.

Szerzői munkamegosztás: A közlemény megírásában minden szerző részt vett. A cikk végleges változatát valamennyi szerző elolvasta és jóváhagyta.

Érdekeltségek: A szerzőknek nincsenek érdekeltségeik.

\section{Irodalom}

[1] Engelhardt, M., Terpos, E., Kleber, M., et al.: European Myeloma Network recommendations on the evaluation and treatment of newly diagnosed patients with multiple myeloma. Haematologica, 2014, 99(2), 232-242.

[2] Radványi, G., Mikala, G., Masszi, T., et al.: Diagnosis and treatment of multiple myeloma (MM). In: Lehoczky, D. (ed.): Current treatment of hematologic diseases. Treatment guideline of the Hungarian Professional Board of Transfusion and Hematology. [A myeloma multiplex (MM) diagnózisa és kezelése. In: Lehoczky, D. (szerk.): Hematológiai betegségek korszerű kezelése. A Magyar Transzfuziológiai és Hematológiai Szakmai Kollégium és a Tudományos Társaság kezelési irányelvei.] Zafír Press, Budapest, 2014. [Hungarian]

[3] Rajkumar, S. V., Dimopoulos, M. A., Palumbo, A., et al.: International Myeloma Working Group updated criteria for the diagnosis of multiple myeloma. Lancet Oncol., 2014, 15(12), e538e548.

[4] Kyle, R. A., Gertz, M. A., Witzig, T. E., et al.: Review of 1027 patients with newly diagnosed multiple myeloma. Mayo Clin. Proc., 2003, 78(1), 21-33.

[5] Fonseca, R., Bergsagel, P. L., Drach J., et al.: International Myeloma Working Group molecular classification of multiple myeloma: spotlight review. Leukemia, 2009, 23(12), 2210-2221.

[6] Klein, B., Seckinger, A., Moebler, T., et al.: Molecular pathogenesis of multiple myeloma: chromosomal aberrations, changes in gene expression, cytokine networks and the bone marrow microenvironment. Recent Results Cancer Res., 2011, 183, 39-86. 
[7] Bergsagel, P. L., Kuehl, W. M., Zhan, F., et al.: Cyclin D dysregulation: an early and unifying pathogenic event in multiple myeloma. Blood, 2005, 106(1), 296-303.

[8] Chapman, M. A., Lawrence, M. S., Keats, J. J., et al.: Initial genome sequencing and analysis of multiple myeloma. Nature, 2011, 471(7339), 467-472.

[9] Lohr, J. G., Stojanov, P., Carter, S. L., et al.: Widespread genomic heterogeneity in multiple myeloma: implications for targeted therapy. Cancer Cell, 2014, 25(1), 91-101.

[10] Egan, J. B., Shi, C. X., Tembe, W., et al.: Whole genome sequencing of multiple myeloma from diagnosis to plasma cell leukemia reveals genomic initiating events, evolution and clonal tides. Blood, 2012, 120(5), 1060-1066.

[11] Broyl, A., Hose, D., Lokhorst, H., et al.: Gene expression profiling for molecular classification of multiple myeloma in newly diagnosed patients. Blood, 2010, 116(14), 2543-2553.

[12] Walker, B. A., Boyle, E. M., Wardell, C. P., et al.: Mutational spectrum, copy number changes, and outcome: Results of a sequencing study of patients with newly diagnosed myeloma. J. Clin. Oncol., 2015, 33(33), 3911-3920.

[13] Lionetti, M., Barbieri, M., Todoerti K., et al.: Molecular spectrum of BRAF, NRAS and KRAS gene mutations in plasma cell dyscrasias: implication of MEK-ERK pathway activation. Oncotarget, 2015, 6(27), 24205-24217

[14] Seckinger, A., Hose, D.: Dissecting the clonal architecture of multiple myeloma. 20th Congress of the European Hematology As sociation, Vienna, Austria. Haematologica, 2015, 9, 173-179.

[15] Walker, B. A., Wardell, C. P., Melchor, L., et al.: Intraclonal heterogeneity is a critical early event in the development of myeloma and precedes the development of clinical symptoms. Leukemia, $2014,28(2), 384-390$.

[16] Keats, J. J., Chesi, M., Egan, J. B., et al.: Clonal competition with alternating dominance in multiple myeloma. Blood, 2012, 120(5), 1067-1076.

[17] Melchor, L., Brioli, A., Wardell, C. P., et al.: Single-cell genetic analysis reveals the composition of initiating clones and phylogenetic patterns of branching and parallel evolution in myeloma. Leukemia, 2014, 28(8), 1705-1715.

[18] Morgan, G. J., Walker, B. A., Davies, F. E., et al.: The genetic architecture of multiple myeloma. Nat. Rev. Cancer, 2012, 12(5), 335-348.

[19] Bianchi, G., Ghobrial, I. M.: Biological and clinical implications of clonal heterogeneity and clonal evolution in multiple myeloma. Curr. Cancer Ther. Rev., 2014, 10(2), 70-79.

[20] Kyle, R. A., Rajkumar, S. V.: Multiple myeloma. N. Engl. J. Med., 2004, 351(18), 1860-1873.

[21] Raja, K. R., Kovarova, L., Hajek, R.: Review of phenotypic markers used in flow cytometric analysis of MGUS and MM and applicability of flow cytometry in other plasma cell disorders. Br. J. Haematol., 2010, 149(3), 334-351.

[22] Fonseca, R., Monge, J., Dimopoulos, M. A.: Staging and prognostication of multiple myeloma. Expert Rev. Hematol., 2014, 7(1), 21-31.

[23] Jenner, E.: Serum free light chains in clinical laboratory diagnostics. Clin. Chim. Acta, 2014, 427, 15-20.

[24] Palumbo, A., Avet-Loiseau, H., Oliva, S., et al.: Revised International Staging System for multiple myeloma: A report from International Myeloma Working Group. J. Clin. Oncol., 2015, 33(26), 2863-2869.

[25] Derlin, T., Bannas, P.: Imaging of multiple myeloma: current concepts. World J. Orthop., 2014, 5(3), 272-282.

[26] Gleeson, T. G., Moriarty, J., Shortt, C. P., et al.: Accuracy of whole-body low-dose multidetector CT (WBLDCT) versus skeletal survey in the detection of myelomatous lesions and correlation of disease distribution with whole body MRI (WBMRI). Skeletal Radiol., 2009, 38(3), 225-236.
[27] Hanrahan, C. J., Christensen, C. R., Crim, J. R.: Current con cepts in the evaluation of multiple myeloma with MR imaging and FDG PET/CT. Radiographics, 2010, 30(1), 127-142.

[28] Mikala, G., Jákó, J., Vályi-Nagy, I.: The role of thalidomide in the treatment of multiple myeloma. [A thalidomid szerepe a myeloma multiplex gyógykezelésében.] Orv. Hetil., 2001, 142(33), 1789-1798. [Hungarian]

[29] Mikala, G., Jákó, J., Vályi-Nagy, I.: Proteasome inhibition: a new therapeutic approach for the treatment of multiple myeloma. [Proteaszómagátlás: új terápiás lehetőség myeloma multiplex kezelésére.] Orv. Hetil., 2004, 145(2), 67-74. [Hungarian]

[30] Varga, G., Mikala, G., Andrikovics, H., et al.: NFKBI -94ins/ delATTG polymorphism is a novel prognostic marker in first linetreated multiple myeloma. Br. J. Haematol., 2015, 168(5), 679-688.

[31] Moreau, P., Pylypenko, H., Grosicki, S., et al.: Subcutaneous versus intravenous administration of bortezomib in patients with relapsed multiple myeloma: a randomised, phase 3, non-inferiority study. Lancet Oncol., 2011, 12(5), 431-440.

[32] Mikala, G., Bátai, Á., Ceglédi, A., et al.: Our experience with bortezomib-based therapy of multiple myeloma based on the first 60 patients. [A myeloma multiplex bortezomibalapú kezelése - Hazai tapasztalatok az első 60 beteg adatainak tükrében.] LAM, 2007, 17(1), 26-34. [Hungarian]

[33] Zimmerman, T. M., Griffith, K. A., Jasielec, J.: Phase II MMRC trial of extended treatment with carfilzomib, lenalidomide, and dexamethasone plus autologous stem cell transplantation in newly diagnosed multiple myeloma. J. Clin. Oncol., 2015, 33(Suppl.), abstr. 8510.

[34] Lokhorst, H. M., Laubach, J., Nabi, H.: Dose-dependent efficacy of daratumumab (DARA) as monotherapy in patients with relapsed or refractory multiple myeloma (RR MM). J. Clin. Oncol., 2014, 32(Suppl.), abstr. 8513.

[35] Lonial, S., Dimopoulos, M. A., Palumbo, A.: ELOQUENT-2: A phase III, randomized, open-label study of lenalidomide/dexamethasone with/without elotuzumab in patients with relapsed/ refractory multiple myeloma. J. Clin. Oncol., 2015, 33(Suppl.), abstr. 8508.

[36] Gorgun, G., Samur, M. K., Cowens, K. B., et al.: Lenalidomide enhances immune checkpoint blockade induced immune response in multiple myeloma. Clin. Cancer Res., 2015, 21(20), $4607-4618$.

[37] Rosiñol, L., Oriol, A., Teruel, A. I.: Superiority of bortezomib, thalidomide, and dexamethasone (VTD) as induction pretransplantation therapy in multiple myeloma: a randomized phase 3 PETHEMA/GEM study. Blood, 2012, 120(8), 1589-1596.

[38] Reeder, C. B., Reece, D. E., Kukreti, V., et al.: Cyclophosphamide, bortezomib and dexamethasone induction for newly diagnosed multiple myeloma: high response rates in a phase II clinical trial. Leukemia, 2009, 23(7), 1337-1341.

[39] Sonneveld, P., Schmidt-Wolf, I. G., van der Holt, B., et al.: Bortezomib induction and maintenance treatment in patients with newly diagnosed multiple myeloma: results of the randomized phase III HOVON-65/GMMG-HD4 trial. J. Clin. Oncol., 2012, 30(24), 2946-2955.

[40] Leiba, M., Kedmi, M., Duek, A., et al.: Bortezomib-cyclophosphamide-dexamethasone (VCD) versus bortezomib-thalidomide-dexamethasone (VTD) -based regimens as induction therapies in newly diagnosed transplant eligible patients with multiple myeloma: a meta-analysis. Br. J. Haematol., 2014, 166(5), 702710.

[41] Painuly, U., Kumar, S.: Efficacy of bortezomib as first-line treatment for patients with multiple myeloma. Clin. Med. Insights Oncol., 2013, 7, 53-73.

[42] Palumbo, A., Bringhen, S., Mateos, M. V., et al.: Geriatric assessment predicts survival and toxicities in elderly myeloma patients: an International Myeloma Working Group report. Blood, 2015, 125(13), 2068-2074. 
[43] Rajkumar, S. V., Jacobus, S., Callander N. S., et al.: Lenalidomide plus high-dose dexamethasone versus lenalidomide plus lowdose dexamethasone as initial therapy for newly diagnosed multiple myeloma: an open-label randomised controlled trial. Lancet Oncol., 2010, 11(1), 29-37.

[44] Richardson, P. G., Weller, E., Lonial, S., et al.: Lenalidomide, bortezomib, and dexamethasone combination therapy in patients with newly diagnosed multiple myeloma. Blood, 2010, $116(5), 679-686$.

[45] San Miguel, J. F., Schlag, R., Khuageva, N. K., et al.: Bortezomib plus melphalan and prednisone for initial treatment of multiple myeloma. N. Engl. J. Med., 2008, 359(9), 906-917.

[46] Morgan, G. J., Davies, F. E., Gregory, W. M., et al.: Long-term follow-up of MRC Myeloma IX trial: Survival outcomes with bisphosphonate and thalidomide treatment. Clin. Cancer Res., 2013, 19(21), 6030-6038.

[47] Facon, T., Mary, J. Y., Hulin, C., et al.: Melphalan and prednisone plus thalidomide versus melphalan and prednisone alone or reduced-intensity autologous stem cell transplantation in elderly patients with multiple myeloma (IFM 99-06): a randomised trial. Lancet, 2007, 370(9594), 1209-1218.

[48] Grey-Davies, E., Bosworth, J. L., Boyd, K. D., et al.: Bendamustine, thalidomide and dexamethasone is an effective salvage regimen for advanced stage multiple myeloma. Br. J. Haematol., 2012, $156(4), 552-555$

[49] Lentzsch, S., O'Sullivan, A., Kennedy, R. C.: Combination of bendamustine, lenalidomide, and dexamethasone (BLD) in patients with relapsed or refractory multiple myeloma is feasible and highly effective: results of phase $1 / 2$ open-label, dose escalation study. Blood, 2012, 119(20), 4608-4613.

[50] Bringhen, S., Petrucci, M. T., Larocca, A., et al.: Carfilzomib, cyclophosphamide, and dexamethasone in patients with newly diagnosed multiple myeloma: a multicenter, phase 2 study. Blood, 2014, 124(1), 63-69.

[51] Stewart, A. K., Rajkumar, S. V., Dimopoulos, M. A., et al.: Carfilzomib, lenalidomide, and dexamethasone for relapsed multiple myeloma. N. Engl. J. Med., 2015, 372(2), 142-152.

[52] Kumar, S. K., Berdeja, J. G., Niesvizky, R., et al.: Safety and tolerability of ixazomib, an oral proteasome inhibitor, in combination with lenalidomide and dexamethasone in patients with previously untreated multiple myeloma: an open-label phase $1 / 2$ study. Lancet Oncol., 2014, 15(13), 1503-1512.

[53] Richardson, P. G., Siegel, D. S., Vij, R., et al.: Pomalidomide alone or in combination with low-dose dexamethasone in relapsed and refractory multiple myeloma: a randomized phase 2 study. Blood, 2014, 123(12), 1826-1832.

[54] Barlogie, B., Velasquez, W. S., Alexanian, R., et al.: Etoposide, dexamethasone, cytarabine and cisplatin in vincristine, doxorubicin and dexamethasone-refractory myeloma. J. Clin. Oncol., 1989, 7(10), 1514-1517.

[55] Barlogie, B., Anaissie, E., van Rhee, F., et al.: Incorporating bortezomib into upfront treatment for multiple myeloma: early results of total therapy 3. Br. J. Haematol., 2007, 138(2), 176185 .
[56] Pozzi, S., Marcheselli, L., Bari, A., et al.: Survival of multiple myeloma patients in the era of novel therapies confirms the improvement in patients younger than 75 years: a population-based analysis. Br. J. Haematol., 2013, 163(1), 40-46.

[57] Mikhael, J. R., Dingli, D., Roy, V., et al.: Management of newly diagnosed symptomatic multiple myeloma: updated Mayo Stratification of Myeloma and Risk-Adapted Therapy (mSMART) consensus guidelines 2013. Mayo Clin. Proc., 2013, 88(4), 360376.

[58] Varga, G., Reményi, P., Mikala, G., et al.: Single center experience with early versus late autologous stem cell transplantation in multiple myeloma. Haematologica, 2015, 100, 652.

[59] Masszi, T.: Hemopoietic stem cell transplantation in Hungary: activity and indications. [Hemopoietikus őssejt-transzplantáció Magyarországon: aktivitás és indikációk.] Transzfúzió, 2000, 33(2), 67-71. [Hungarian]

[60] Cook, G., Williams, C., Brown, J. M., et al.: High-dose chemotherapy plus autologous stem-cell transplantation as consolidation therapy in patients with relapsed multiple myeloma after previous autologous stem-cell transplantation (NCRI Myeloma $\mathrm{X}$ Relapse [Intensive trial]): a randomised, open-label, phase 3 trial. Lancet Oncol., 2014, 15(8), 874-885.

[61] Vesole, D. H., Zhang, L., Flomenberg, N., et al.: A phase II trial of autologous stem cell transplantation followed by mini-allogeneic stem cell transplantation for the treatment of multiple myeloma: an analysis of Eastern Cooperative Oncology Group ECOG E4A98 and E1A97. Biol. Blood Marrow Transplant., 2009, 15(1), 83-91.

[62] Rajkumar, S. V., Harousseau, J. L., Durie, B., et al.: Consensus recommendations for the uniform reporting of clinical trials: report of the International Myeloma Workshop Consensus Panel 1. Blood, 2011, 117(18), 4691-4695.

[63] Chen, C. I., Masib-Khan, E., Jiang, H., et al.: Central nervous system involvement with multiple myeloma: long term survival can be achieved with radiation, intrathecal chemotherapy, and immunomodulatory agents. Br. J. Haematol., 2013, 162(4), 483-488.

[64] Ashley, C., Dunleavey, A. (eds.): The renal drug handbook. Radcliffe Publishing, London, 2014.

[65] Sinkó, J., Cser, V., Konkoly Thege, M., et al.: Gram-negative bacteremia in neutropenic patients with hematologic disorders. Experiences with prophylactic use of fluoroquinolones. [Gram-negatív bacteriaemia neutropeniás hematológiai betegekben. Tapasztalatok fluorokinolonprofilaxis alkalmazása kapcsán.] Orv. Hetil., 2011, 152(27), 1063-1067. [Hungarian]

[66] Snowden, J. A., Ahmedzai, S. H., Ashcroft, J., et al.: Guidelines for supportive care in multiple myeloma 2011. Br. J. Haematol., $2011,154(1), 76-103$.

(Varga Gergely dr., Budapest, Kútvölgyi út 4., 1125 e-mail: vargager@gmail.com) 